Edil Ferreira da Silva ${ }^{1}$

Keila Kaionara Medeiros de Oliveira²

Paulo César Zambroni-de-Souza ${ }^{3}$

\section{Saúde mental do trabalhador: o assédio moral praticado contra trabalhadores com LER/DORT*}

\author{
Worker's mental health: moral harassment at work against \\ workers with Repetitive Strain Injuries/Work Related \\ Musculoskeletal Disorders
}

1 Professor do Departamento de Psicologia da Universidade Estadual da Paraíba (UEPB).

2 Psicóloga, ex-orientanda de iniciação científica do Departamento de Psicologia da Universidade Estadual da Paraíba (UEPR).

3 Professor do Mestrado em Psicologia Social da Universidade Federal da Paraíba (UFPB).

* Pesquisa fomentada pelo Programa Institucional de Bolsas de Iniciação Científica (PIBIC/CNPq/UEPB).

Contato:

Edil Ferreira da Silva

Rua Ephigênio Barbosa da Silva, 450, Bloco A - Apto 203 - Jardim Cidade Universitária - João Pessoa-PB

E-mail:

edilsilva@uol.com.br

\section{Resumo}

Este artigo analisa como o assédio moral se configura na vida dos portadores de lesões por esforços repetitivos/distúrbios osteomusculares relacionados ao trabalho (LER/DORT). Participaram do estudo, realizado em 2007, 20 trabalhadores acometidos por LER/DORT de uma indústria do calçado em Campina Grande-PB. Empregaram-se entrevista semiestruturada e análise de conteúdo. Os resultados apresentam um quadro de assédio moral interpessoal e organizacional que está bem configurado nas histórias de adoecimento dos trabalhadores e nas suas trajetórias de busca de ajuda para seus problemas de saúde. O assédio moral interpessoal e organizacional se evidencia em virtude de todos os aspectos de humilhação, exclusão e pressão que recebem no ambiente de trabalho, sob forma de coação, subversão, chantagem e rebaixamento. Para não terem que sofrer com o desemprego, alguns preferem pedir demissão, outros suportam as dores, ultrapassando os limites do corpo. A lógica da produção de assédio moral e organizacional destrói a solidariedade e impede que os trabalhadores construam coletivamente formas de enfrentamento do trabalho.

Palavras-chave: saúde mental e trabalho; assédio moral; saúde do trabalhador; gestão do trabalho.

\begin{abstract}
This article analyzes how moral harassment was introduced in the lives of workers with Repetitive Strain Injuries/Work-Related Musculoskeletal Disorders (RSI/WRMD). In 2007, twenty workers with RSI/WRMD from a footwear industry in Campina Grande- Paraiba, Brazil took part in a study conducted by means of semistructured interviews and content analysis. The results presented a panorama of interpersonal and organizational moral harassment that is clearly shown in the workers' illness reports and in their trajectories searching for help for their health problems. Interpersonal and organizational moral harassment is evidenced by humiliation, exclusion and pressure received at workplace. It is shaped as coercion, subversion, blackmailing and demotion. To avoid unemployment, some workers would rather resign, others would bear pain, which could exceed their limits. The logic of the production of moral and organizational harassment destroys and prevents workes from structuring ways of confronting the problem collectively.
\end{abstract}

Keywords: mental health and work; moral harassment; worker's health; work management. 


\section{Introdução}

Este artigo aborda o assédio moral sofrido pelos trabalhadores de uma indústria de calçado de grande porte, acometidos de lesões por esforços repetitivos/distúrbios osteomusculares relacionados ao trabalho (LER/ DORT). A análise aqui realizada toma como base a linha de pensamento que relaciona o assédio moral com a organização do trabalho e seu modo de gestão.

Para conseguir dar conta das metas de produção impostas, os trabalhadores do setor calçadista em Caminha Grande-PB se desdobram nos processos de trabalho denominados de células de trabalho e grupos de trabalho. São novas formas de trabalho com velhas formas de controle, exigências e constrangimentos diversos. O engajamento dos trabalhadores nesse processo absorve suas energias físicas e psíquicas.

Para manter os níveis de produção, todos são exigidos no máximo de suas potencialidades físicas e mentais. Os meios para atingir as metas são diversos (prêmio de produção, por exemplo), entretanto, o resultado desse esforço das empresas e dos trabalhadores não é somente os produtos em quantidade e qualidade para exportação. As situações de trabalho desse ramo industrial têm deixado um contingente significativo de trabalhadores com doenças provocadas pelo trabalho. Quando acometidos por doenças, eles passam a ser mais discriminados no ambiente de trabalho, sofrem humilhações, vexames, cobranças de produtividade e pressões dos superiores. $\mathrm{O}$ assédio moral se configura nas situações de trabalho do setor calçadista dessa região.

\section{Lesão por esforço repetitivo (LER)/Distúrbios osteo- musculares relacionados ao trabalho (DORT)}

Entende-se LER/DORT (INSTITUTO NACIONAL DO SEGURO SOCIAL, 2003) como uma síndrome relacionada ao trabalho, caracterizada pela ocorrência de vários sintomas, concomitantes ou não, tais como: dor, parestesia, sensação de peso, fadiga de aparecimento insidioso, geralmente nos membros superiores, mas que também pode acometer os membros inferiores. Ainda segundo o Instituto Nacional do Seguro Social (2003):

a necessidade de concentração e atenção do trabalhador para realizar suas atividades e a tensão imposta pela organização do trabalho são fatores que interferem de forma significativa para a ocorrência das LER/DORT. (s.p.)

Foi com o advento da Revolução Industrial que quadros clínicos decorrentes de sobrecarga do sistema osteomuscular tornaram-se mais numerosos. Entretanto, no Brasil, seu registro começa a ser mais frequentemente estabelecido a partir de 2007, com a Instrução Normativa INSS/PRES n⿳ำ 16 (INSTITUTO NACIONAL DO SEGURO SOCIAL, 2007). Tanto no caso brasileiro, quanto em outros países, os fatores explicativos para o grande número de acometidos, mesmo que a incidên- cia exata seja ainda desconhecida, são diversos, porém aqueles relacionados ao processo e à organização do trabalho são os preponderantes (COUTO; MORAES, 2003; FREITAS; HELOANI; BARRETO, 2009; DEJOURS; BÈGUE, 2010; FREITAS; LIMA; ANTONIO, 2010).

$\mathrm{Na}$ contemporaneidade, uma nova organização do trabalho se configurou, em nível mundial, a partir de grandes transformações econômicas, sociais, políticas e culturais. Nesse bojo, o aspecto econômico foi alçado à categoria de valor supremo, com resultados nefastos para a identidade das pessoas. No campo social, as referências pautam-se na valorização do indivíduo como consumidor e, no âmbito do trabalho, a avaliação individualizada de desempenho privilegia a quantificação (FREITAS; HELOANI; BARRETO, 2009; DEJOURS, 2008). Segundo Freitas, Heloani e Barreto (2009):

a nova organização do trabalho alterou completamente a relação com o tempo e o espaço e tem se desenvolvido cada vez mais como um fluxo, prescindindo de vínculos sociais duradouros ou referências no passado. (p. 6-7)

As mudanças perpetradas no processo e na organização do trabalho trazem consequências para o emprego e os direitos sociais. Os empregos que mais crescem na atualidade são aqueles relacionados ao trabalho temporário e em tempo parcial. Cada vez mais os trabalhadores têm seus benefícios sociais reduzidos e, em diversos casos, excluídos. O desemprego é um fantasma que ronda todo o planeta (ANTUNES; ALVES, 2004), mesmo que no caso brasileiro tenha havido diminuição da taxa de desemprego nos últimos meses, como apontam dados do Instituto Brasileiro de Geografia e Estatística (2010a). Todos esses aspectos levam a mudanças radicais no modo de organizar os trabalhadores no ambiente de trabalho.

Nessa perspectiva, o trabalho vai perdendo o seu caráter coletivo e o indivíduo, cada vez mais, vai sendo responsabilizado e, sobretudo, culpabilizado pelos seus atos. Como afirma Dejours (2007, p. 22), "a individualização degrada-se então para o cada-um-por-si, a concorrência vai até condutas desleais entre os colegas, a desconfiança instala-se entre os agentes". Na atualidade, como afirmam Freitas, Heloani e Barreto (2009):

o vínculo profissional ganha relevância paradoxal,
pois estamos falando de um mundo em que o vín-
culo com o trabalho tende a ser cada vez mais raro,
mais curto e mais superficial, ao mesmo tempo em
que se torna a referência central a testemunhar a
existência do indivíduo. (2009, p. 8-9)

O novo método de organização do trabalho, calcado na avaliação individualizada dos desempenhos que se implementou nos últimos anos, trouxe igualmente efeitos deletérios sobre o trabalho coletivo e a cooperação. Para Dejours, "a avaliação individualizada assenta-se no princípio de uma análise quantitativa e objetiva do trabalho, passando pela mensuração dos resultados” (DEJOURS; BÈGUE, 2010, p.44). Esse tipo de avaliação, que não mede o trabalho efetivamente realizado, mas 
tão somente seus resultados (DEJOURS, 2008), acaba por criar a concorrência no meio do trabalho em que se incluem os trabalhadores. Quando a avaliação individualizada do desempenho é usada para atribuir conceito ou algum tipo de prêmio aos trabalhadores, a convivência entre eles se complica mais ainda e a concorrência aumenta. Dejours e Bègue destacam que, se à avaliação individualizada de desempenho for acrescida “a ameaça de ser colocado na 'geladeira', da transferência sumária, da queda em desgraça, da demissão”, surgirão "condutas de concorrência e de rivalidades que derivam em condutas desleais”. Assim, o contexto do trabalho se modifica, e "a lealdade e a confiança são corroídas e são trocadas pela desconfiança e o constrangimento de vigiar o comportamento dos colegas, logo considerados como adversários” (2010, p. 46).

Nos últimos anos, no mundo do trabalho, ganhou contorno uma:

organização do trabalho cada vez mais sem compromissos com o ser humano, pois sua fórmula mágica é enfocada na garantia de ganhos de produtividade crescentes no curto prazo. (FREITAS; HELOANI; BARRETO, 2009, p. XVI).

Esse modo contemporâneo de organizar o trabalho produz violência contra as pessoas que trabalham. De acordo com a Organización Internacional del Trabajo (2003), a violência no trabalho compreende todos os tipos de comportamentos agressivos e abusivos que tendem a causar danos físicos, psicológicos ou desconforto em suas vítimas. A violência psicológica no trabalho é uma das que mais têm aparecido e provocado consequências diversas para aqueles que são vítimas dela. Gosdal et al. (2009) referem que:

a violência psicológica no trabalho, que inclui o assédio moral, pode trazer sérias perturbações à saúde física e mental do empregado assediado e também dos colegas não partícipes do assédio, criando um ambiente de trabalho hostil e desagradável, carregado de tensões. (p. 40)

\section{Assédio moral}

Embora o assédio no ambiente laboral seja tão antigo quanto o próprio trabalho, Leymann (1996), um dos pioneiros a tratar desse assunto, lembra que foi Brodsky, em 1976, quem primeiro estudou casos de mobbing, mas reitera que ele "não estava interessado em analisar esses casos” (p. 4). Foi o próprio Leymann, no início dos anos 1980, que passou a estudar a prática do mobbing no mundo do trabalho. De acordo com Hirigoyen (2000), foi somente no início da década de 1990 que o assédio moral passou a ser alvo de estudos e seus resultados usados na criação de dispositivos legais. Os estudos se multiplicam, principalmente, devido ao fato do problema ser identificado como fenômeno destruidor do ambiente de trabalho, causando não apenas baixa de produtividade, como também o absenteísmo devido ao desgaste psicológico que provoca.
Além de Leymann, internacionalmente, outra grande referência acerca do assunto compete à Marie-France Hirigoyen, que publicou na França, em 1998, o livro que ganhou grande alcance sobre a questão, intitulado Le Harcèlement Moral: la violence perverse au quotidien (HIRIGOYEN, 2000). Nesse livro, a autora aborda o assédio moral a partir do ponto de vista do assediador, ou seja, de quem agride a integridade do outro, e como se processa o assédio. A autora tipifica vários tipos de assediadores e as consequências disso sobre o trabalhador assediado. Segundo a autora, o assédio moral gera medo, desconfiança, até um estado de paranoia, em que o trabalhador se sente perseguido, ultrapassa os muros do trabalho e invade, inclusive, o âmbito social. Matias (2004) afirma que esse livro teve como resultado as bases legais que tratam do assédio moral na França.

No Brasil, um estudo de grande importância acerca do tema é a dissertação de Mestrado de Margarida Barreto, posteriormente publicada com o título Violência, saúde e trabalho: uma jornada de humilhações (BARRETO, 2003). Esse estudo sistematiza e visibiliza o tema na sociedade brasileira.

Hirigoyen (2002, p. 17) define o assédio moral no trabalho como sendo:

toda e qualquer conduta abusiva (gesto, palavra, comportamento, atitude...) que atente, por sua repetição ou sistematização, contra a dignidade ou a integridade psíquica ou física de uma pessoa, ameaçando seu emprego ou degradando o clima de trabalho.

Para Soboll (2008, p. 21):

assédio moral é uma situação extrema de agressividade no trabalho, marcada por comportamentos ou omissões, repetitivos e duradouros. Caracteriza-se por sua natureza agressiva, processual, pessoal e mal-intencionada.

O assédio moral decorre de um desvio no exercício do poder nas relações de trabalho. Essa situação cria um ambiente hostil, desestabilizador. Nesse clima de medo, e no contexto de desemprego, o trabalhador aceita mais passivamente as situações criadas e é menos reivindicativo. Como afirmam Eberle, Soboll e Cremasco (2009, p. 113):

as práticas organizacionais ou gerenciais que utilizam de ameaças acabam por mobilizar o medo nos trabalhadores, que pode ser expresso de diversas maneiras, como medo de ser humilhado, de não corresponder às exigências da empresa, de ser demitido etc.

Peli e Teixeira (2006) diferenciam três tipos de relações assediadoras que se classificam como relações de posições hierárquicas: assédio moral descendente - caracterizado pela ação de um superior hierárquico sobre um subordinado; assédio moral horizontal - caracterizado pela ação entre pessoas do mesmo nível hierárquico; e assédio moral ascendente - caracterizado pela ação de baixo para cima, ou seja, de um subordinado em relação ao seu superior hierárquico. Mesmo sendo menos frequente, esse tipo de assédio pode ser comumente encontrado em empresas públi- 
cas onde a estabilidade no trabalho e a rotatividade da gestão estão sempre em andamento. Os autores enfocam a importância de diferenciar o assédio da discriminação. O primeiro se reveste com características de humilhar, independentemente de atributos pessoais da vítima, enquanto o segundo se dá tanto pela retirada ou pela restrição de um direito, como por questões raciais ou, ainda, em relação a pessoas portadoras de alguma necessidade especial.

O assédio moral pode ser considerado como um ato individual perverso, bem como o resultado de contextos de trabalho propícios ao seu desenvolvimento (DEJOURS, 2001). Nessa linha de pensamento, não é preciso estabelecer uma análise mais detalhada da sociedade para se perceber que o modo de vida moderno contribui para um isolamento e uma individualização sociais em que cada qual está voltado mais para si, para seus problemas.

Dejours (2001) fala do assédio moral como uma "patologia da solidão”. Vallete (2002) afirma que Dejours define assédio moral e mobbing como sendo:

[...] uma forma clínica específica de alienação social no ambiente de trabalho, resultante de pressões psíquicas sobre o sujeito oriundas do exterior pela organização do trabalho, seus modos de gestão, avaliação ou de direção das empresas. O assédio ou Mobbing eleva ao extremo a marginalização do sujeito. (p. 74-75)

Quanto às empresas, de uma forma geral, preferem não evitar que tais situações ocorram, o que colabora, indiretamente, para a intensificação do mal (HIRIGOYEN, 2002).

Peli e Teixeira (2006, p. 63) confirmaram a conivência das empresas. Os autores destacam que há uma clara omissão das organizações sobre a questão do assédio moral e que isso ocorre de forma silenciosa. "Prevalece, quase sempre, certa outorga de poderes (não controlados) concedida a um gestor empreendedor", na maioria das vezes, responsável por resultados e que "indiretamente reconhece como normais os estilos mais agressivos no campo da competição”. Nessa mesma linha, Pezé (2008, p. 41) afirma que "os comportamentos tirânicos, o assédio, a perseguição a um subalterno são frequentes e integrados ao modo de gerenciamento". Dessa maneira, o assédio pode se caracterizar como instrumento de gestão em uma tentativa de subjugar o trabalhador para que ele se submeta ao máximo aos imperativos da produção.

Da parte do agredido, acrescentam-se vários estágios, como renúncia, confusão, dúvida, estresse, medo e isolamento:

Ao instalarem-se o enredamento e o controle as vítimas vão-se tornando cada vez mais confusas, sem saber ou ousar queixar-se. Ficam como que anestesiadas, queixam-se de ter um vazio na cabeça e dificuldade de pensar, descrevem o próprio empobrecimento, um aniquilamento parcial de suas faculdades, uma amputação do que elas tinham de mais vivo e espontâneo. (HIRIGOYEN, 2000, p. 170)
Nesse contexto, o coletivo de trabalho fica paralisado diante de uma situação com a qual não sabe como lidar e sobre a qual se sente anestesiado, evitando comentários e negando a realidade. Conforme Pezé (2008), "o medo de perder seu emprego e seus direitos sociais neutralizou a mobilização coletiva, gerou o silêncio e o ‘cada um por si”” (p. 43).

De fato, não apenas os coletivos ficam anestesiados diante de tais situações, como também as formas de gestão cada vez mais adotadas nas empresas procuram impedir a formação de coletivos, na medida em que não são oferecidas condições aos trabalhadores para perceberem que permanecerão por longo tempo na organização, de modo que o "[...] princípio do "não há longo prazo’ também atinge as relações e os laços sociais, corroendo a 'confiança, a lealdade e o respeito mútuo"” (EBERLE; SOBOLL; CREMASCO, 2009, p. 105). Isso acaba por criar ambientes propícios ao surgimento e ao crescimento de violência no trabalho, visto que, diante de ações violentas que surgem, não há um coletivo para defender aqueles que sofrem (op. cit., p. 109-110).

As pesquisas que abrangem o tema demonstram que a violência empregada no uso e no abuso do poder é explicitada através da intensificação do trabalho, da precarização dos empregos (postos de trabalho) e do desmoronamento das regras de solidariedade que são construídas nos coletivos de trabalho (GENEST; LECLERC; MARANDA, 2005). Existem algumas pessoas que são mais submetidas às situações de assédio do que outras. É o caso do assédio em função de deficiência física ou doença (HIRIGOYEN, 2000), como acontece com os sujeitos de que trata este artigo.

Aqui, adotamos a definição de assédio moral proposta por Schatzman et al. (2009, p. 17), que o concebem como "um processo sistemático de hostilização, direcionado a um indivíduo, ou a um grupo, que dificilmente consegue se defender dessa situação”. Nessa linha, é importante fazer a diferenciação do assédio moral interpessoal (ou simplesmente assédio moral) do assédio moral organizacional (ou simplesmente assédio organizacional) para se evitarem análises incorretas. Soboll (2008, p. 21) define o assédio organizacional como sendo:

um processo no qual a violência está inserida nos
aparatos, nas estruturas e nas políticas organiza-
cionais ou gerenciais, que são abusivas e inade-
quadas. O propósito é exercer o gerenciamento do
trabalho e do grupo visando produtividade e con-
trole organizacional.

O assédio organizacional visa manter o controle sobre a coletividade de trabalhadores, diferentemente do assédio moral, cujo alvo é direto. Soboll (2008) refere que o assédio organizacional se configura através de algumas práticas, como gestão por estresse, gestão por injúria, gestão por medo, exposições constrangedoras de resultados, premiações negativas, ameaças, cobranças exageradas. Na análise de Soboll, "essas estratégias de gestão funcionam como uma técnica de aumento do 
envolvimento no trabalho e também podem ter o efeito de um processo de 'seleção natural' dos menos resistentes" (2008, p. 22).

Soboll (2008, p. 22-23) aponta a diferença entre assédio organizacional e assédio moral. Segundo ela:

no assédio moral, a empresa é palco da violência, e o objetivo é prejudicar, excluir ou anular o trabalhador que se transformou em persona non grata. No assédio organizacional, o objetivo é exercer o controle sobre a coletividade e garantir o alcance dos objetivos organizacionais e gerenciais.

O assédio organizacional torna-se pernicioso aos trabalhadores na medida em que as condutas das pessoas passam a ser abusivas e atentam contra a dignidade humana.

Sob nosso ponto de vista, na empresa que é o objeto de estudo desta pesquisa, pratica-se o assédio organizacional indiscriminadamente, mas quando os trabalhadores adoecem por LER/DORT, passam a ser alvos privilegiados de assédio, ou seja, tornam-se vítimas de assédio moral interpessoal, como veremos adiante.

\section{Metodologia}

A presente pesquisa é do tipo transversal e analítica. A metodologia utilizada é de cunho qualitativa. Dejours, Abdoucheli e Jayete (1994) asseveram que, nesse tipo de pesquisa, não se trata apenas de verificar a relação saúde mental-trabalho, nem somente de averiguar "o estado das coisas" em um dado momento. Para os autores, é preciso "catalisar a dinâmica da revelação-construção no sentido do vivenciado, do sofrimento no trabalho" e levantar a vivência subjetiva no trabalho para se ter acesso ao sofrimento, passando, necessariamente, pela palavra do trabalhador.

A entrevista individual semiestruturada foi empregada por meio de um roteiro, que possibilitou abordar aspectos da organização do trabalho e da vivência subjetiva do trabalhador. A escolha de um formato de roteiro semiestruturado permitiu a flexibilidade nas conversas e a absorção de categorias empíricas trazidas pelos entrevistados.

O roteiro elaborado para a entrevista foi montado em duas partes. Na primeira, focou-se o aparecimento dos primeiros sintomas da doença, como era o trabalho antes do adoecer, assim como o sofrimento vivenciado pelo acometimento das LER/DORT. Também se investigaram as relações que se estabelecem no trabalho durante o processo de desencadeamento da doença, a cobrança quanto à produtividade e, ainda, colocaram-se questões acerca de como os trabalhadores conseguem trabalhar mesmo sentindo dores, o enfrentamento de novas questões como o afastamento do trabalho e a correlação das vivências que se estabelecem dentro de casa depois do afastamento. $\mathrm{Na}$ segunda parte, as questões foram voltadas para o relato dos adoentados que passaram pelo processo de retorno ao trabalho depois de ficarem afastados, os mecanismos adotados pelos trabalhadores frente ao assédio moral vertical (praticado por superiores hierárquicos) e ao assédio moral horizontal (praticado pelos colegas de trabalho de mesmo nível hierárquico) quando retornaram ao trabalho e/ou foram transferidos para outro setor.

Participaram da pesquisa 20 operários acometidos por LER/DORT (18 homens e duas mulheres). Todos os trabalhadores entrevistados estavam em tratamento e pertenciam a uma mesma empresa do ramo calçadista. As entrevistas foram realizadas em um setor de Fisioterapia de uma clínica privada de ortopedia e trauma em Campina Grande. Todos os trabalhadores tinham convênio médico pago pela empresa. As entrevistas foram realizadas entre janeiro e maio de 2007.

Os dados das entrevistas foram analisados de acordo com o método da análise de conteúdo, a partir da análise temática. Dividimos os discursos em categorias analíticas e categorias empíricas, organizadas com base nas entrevistas, que foram cuidadosamente transcritas, mantendo-se o conteúdo explicitado pelos trabalhadores. Foi construído um quadro temático com as categorias analíticas e empíricas, de onde foram retirados e distribuídos os discursos que se adequavam a cada categoria. Neste artigo, os resultados são apresentados a partir de cinco categorias, a saber: a coação viril como forma de manter a produção; agravos e sintomas: motivos de humilhações e constrangimentos; (des)cuidados médicos; atestado médico: uma fonte de pressão psicológica no trabalho; e outras situações de assédio moral.

\section{Resultados e discussão}

O pano de fundo dos assédios moral e organizacional de uma empresa do setor calçadista em Campina Grande

A cidade de Campina Grande tem 385.227 mil habitantes, segundo o Instituto Brasileiro de Geografia e Estatística (IBGE, 2010b). Em doze meses (nov./09 a out./10), o saldo de empregos formais criados na Paraíba foi de 23.426. O estado ocupou o sexto lugar na criação de emprego formal no Nordeste, ficando à frente apenas de Sergipe, Piauí e Alagoas (BRASIL, 2010). A maior empresa de produção de calçados da Paraíba se destacou como uma das principais empresas exportadoras do ramo calçadista do Brasil em 2008, com uma participação de $30,20 \%$ do volume total de recursos arrecadados por todas as empresas no estado (FEDERAÇÃO DAS INDÚSTRIAS DO ESTADO DO PARANÁ, 2008).

Por força do incremento da exportação no setor calçadista, as metas de produção tornaram-se cada vez mais altas. A atividade de acabamento é o setor que emprega o maior contingente de trabalhadores. Nesse setor, o processo de trabalho se configura a partir de grupos de trabalho ou células de trabalho. De acordo com Gondim (2007, p. 24): 
nos grupos e nas células, são operados os equipamentos utilizados no processo de acabamento das sandálias produzidas, seguindo os procedimentos de trabalho indicados no local, mantendo o padrão de qualidade exigida pela empresa. O processo de trabalho nos grupos e células se diferencia por empregar uma organização do trabalho heterogênea. Nos grupos cada trabalhador é responsável por uma determinada tarefa no processo de produção. Já nas células todos os operários devem realizar todas as tarefas, adotando-se um sistema de rodízio de funções. Nos grupos há maior número de funcionários do que nas células.

O processo produtivo é acompanhado por supervisores, que ficam o tempo todo vigiando e cobrando o cumprimento das instruções de trabalho. O processo de trabalho da produção do calçado por célula ou grupo é bastante repetitivo, apesar do emprego do rodízio entre funções nas células de trabalho. A prescrição das tarefas é bastante detalhada e, para cada função, um conjunto de normas deve ser obedecido. Para cada peça e seus complementos, o trabalhador precisa aprender o modo padrão de operar. Como os modos operatórios são bastante repetitivos, os trabalhadores são treinados para repeti-los tal qual observado e praticado.

Apesar do rodízio nas células de trabalho, a flexibilidade da atividade fica limitada pela cobrança por produção e cumprimento de metas, o que faz com que haja intensificação do trabalho. O rodízio de funções é estabelecido pelos trabalhadores, mas a pretensa autonomia desta ação é perdida pelas cobranças dos líderes que exigem que a mudança seja feita apenas conforme a prescrição. Os trabalhadores não estabelecem entre eles o melhor modo de fazer o rodízio, já que os líderes ficam o tempo todo vigiando para saber se eles estão trocando mesmo de função como prescrito. Embora pareça paradoxal, o coletivo fica tolhido em sua autonomia. O que deveria ser algo positivo, devido à repetitividade, torna-se um sofrimento pela obrigação do ato, fazendo com que a burla desta norma tenha que ser feita com mais cuidado, visto que a vigilância é constante.

Segundo Gondim (2007), “o uso do macete é uma prática corrente na empresa por força da existência da discrepância entre a tarefa prescrita e a atividade”. Para a autora a questão da transgressão da prescrição fica evidente nas falas dos trabalhadores entrevistados em sua pesquisa sobre a constituição de coletivo de trabalho nesta mesma empresa, quando explicitam que fazem do seu jeito sem que o supervisor perceba. Ela diz que esta ação pode levar ao sofrimento, já que a organização do trabalho não permite que o trabalhador possa livremente usar de sua inteligência prática para dar conta da organização da produção. Subverter a prescrição é necessário, mas isso é conseguido a custa de muita astúcia.

\section{A coação viril como forma de manter a produção}

Quando sentem que estão adoecendo, os trabalhadores aguentam a dor, escondem dos colegas, mas não podem esconder o desgaste físico quando não conseguem dar conta da tarefa exigida. Nesse sentido, começam a ser advertidos pela baixa de produtividade. Devido às dores, o rendimento diminui e é percebido pelos colegas de trabalho e pela chefia. Em consequência disso, no decorrer do tempo, passam a ser chamados pelos supervisores até a "salinha", onde são cobrados e coagidos. Os supervisores exercem, assim, o papel de vigilantes da produção, inclusive como uma forma de mostrar para os outros operários que não se tolera baixa de produção. Criticam quando os operários se queixam de dor e os chamam de moles, maricas, preguiçosos. Vemos, aqui, o exercício do assédio organizacional pelos supervisores na medida em que se busca estimular a produtividade, manter o nível de produção, através de condutas hostis e agressivas para obter maior controle sobre os trabalhadores.

Eita que tem gente aqui que não quer mais trabalhar não! Mas não tem nada não! Do mesmo jeito que entra gente, sai gente aqui! A fila aqui é muito grande [imitando a forma de falar do supervisor]. (Homem, 21 anos)

Como afirma Soboll (2008, p. 174), "as descompensações na saúde são tratadas como se fossem escolhas dos trabalhadores, como uma forma de 'comportamento desviante' na lógica produtiva".

A coação se efetiva de forma direta também. Uma entrevistada contou que isso ocorreu quando um líder foi demonstrar para o trabalhador que ele não estava atingindo o tempo necessário para a produção da peça. Para tanto, utilizou um relógio para marcar o tempo da atividade realizada:

Eles usam também um relógio, um relógio que o su-
pervisor manda o líder fazer, assim não é bom. Porque
se você consegue fazer sete pares num minuto, eles
ficam marcando, ficam olhando, lhe observando, eles
contam um minuto, se você não fizer aquela marca aí
eles já vão reclamar com você, vai exigir de você. Aí
você tem que fazer, tem que fazer, tem que fazer, até
alcançar aquela meta. Eles ficam pressionando, por-
que você está num lugar, fazendo uma coisa, e uma
pessoa lhe observando, fazendo aquilo, você fica ner-
voso, eu mesma fico nervosa, eles ficam assim ó [mos-
trando a proximidade entre o líder que cronometra e o
operário que trabalha]. (Mulher, 30 anos)

Executar um bom trabalho, nos moldes atuais de competitividade capitalista, significa, necessariamente, ter que acompanhar os ritmos impostos à produção. Atingir as metas é a prioridade empresarial e, em concordância, devem os funcionários fazer de tudo para não apenas as alcançar, mas superá-las. As exigên-

${ }^{4}$ A "salinha" é o local para onde são levados os operários que não cumprem a produção. Lá, eles são advertidos, mas, nas palavras dos trabaIhadores, eles eram "enrabados", "levavam uma trepada" do supervisor. A salinha foi uma das categorias empíricas analisadas em Oliveira e Silva (2006). 
cias são tão grandes que muitas vezes não apenas os adoentados, mas também os outros trabalhadores têm enorme dificuldade de dar conta da produção, pois se trata de um ritmo de trabalho muito intenso. Por isso, são destratados com palavras impróprias para uma relação normal de trabalho. Essa situação ilustra o que encontramos nessa empresa: o assédio organizacional utilizado como instrumento de gestão, isto é, a constante pressão acompanhada de humilhação para que os trabalhadores possam dar conta das metas:

\section{Errar? Errar você pode errar, o primeiro erro, segun- do eles podem aliviar, mas a terceira eles não, princi- palmente o gerente lá, ele trata super mal: "puta ve- lha!”; "vocês são um bocado de puta velha, rapaz!”; "vocês não sabem trabalhar direito!", chama a gente de puta velha. (Homem, 27 anos)}

Evidenciamos, nessas palavras, que, no caso dos operários homens, visam destituí-los de sua masculinidade e, em relação às mulheres, colocam-nas na categoria de "putas", demonstrando, mais uma vez, o exercício da virilidade em uma relação desigual de força. Esse é um exercício que visa manter os supervisores em uma posição de grande poder masculino, no sentido em que fala Dejours (2007, p. 87) quando diz que "muitos são os homens que aceitam participar do 'trabalho sujo', tornando-se assim 'colaboradores' do sofrimento e da injustiça infligidos a outrem”.

\section{Dejours (2001, p.1) afirma que:}

no trabalho hoje, os pretextos de eficácia e competitividade chamam os executivos a colaborar com as estratégias das empresas, a se tornarem quites a infringir com o sofrimento e a injustiça com os outros.

A banalização do mal, como denomina o autor, é eficazmente construída e justificada pelas regras de mercado.

Seguindo as estratégias empresariais, o trabalhador é uma peça descartável, principalmente quando está acometido por alguma doença que o impede de acompanhar o ritmo da produção, ainda mais no universo de desemprego vivido no Brasil, especificamente, na região onde a pesquisa foi desenvolvida. A doença do trabalhador que está relacionada ao trabalho é usada para acusá-lo de ineficiência. O mais grave é que é utilizada para fazer com que ele se resigne e volte a produzir.

Quando eu dizia que não podia, eles ameaçavam: "se você não puder não venha trabalhar! Procure um médico e vá pra casa [...] porque ninguém quer ninguém trabalhando aqui doente não [...] qualquer coisa se você não quiser trabalhar tá cheio de gente lá fora que quer!”. (Homem, 49 anos)

De fato, a rotatividade gerada por demissões pela empresa ou requeridas pelos trabalhadores, quando não mais suportam permanecer naquela situação, aliada ao conhecimento que os trabalhadores têm do contingente de desempregados que desejam uma colocação naquela empresa é fonte de grande pressão para os que continuam trabalhando. Para piorar essa situação, o sofrimento vivido nas situações de trabalho tende a ser negado pelos próprios trabalhadores, visto que avaliam ser melhor suportar o sofrimento do que arriscar cair no desemprego (DEJOURS, 2007). Muitos deles permanecem no trabalho, mesmo doentes, o que caracteriza o fenômeno que vem sendo denominado de presenteísmo. Segundo Seligmann-Silva, presenteísmo:

significa que pessoas adoecidas estão trabalhando sem manifestar queixas e em geral sem procurar tratamento, ao mesmo tempo em que seus quadros clínicos se agravam e cronificam enquanto, inevitavelmente o desgaste atinge também seu desempenho. (2010, p. 3)

Ultrapassar os empecilhos inerentes ao trabalho real com uma gestão vigilante e disciplinadora é sempre difícil para os operários. Na maioria das vezes, o uso dos "macetes" é feito às escondidas para que o líder não perceba e puna o trabalhador (GONDIM, 2007). E quando o operário tem uma limitação para atingir a produção requerida, isso se torna mais complicado.

Os incidentes, as quebras de máquinas, os defeitos que param a produção são situações de mal-estar para o trabalhador. Para os líderes e os supervisores, não importa quais os motivos, sempre tem que se dar conta da produção. Surgem daí as humilhações, mostrando novamente o assédio organizacional como um instrumento de gestão. Aparecem como forma de pressão a suspensão e a perda do dia de trabalho já no final da jornada diária:

Se a produção não dá, eles perguntam "por quê?" A gente diz, eles falam que não é motivo, eles aproveitam o embalo com a raiva, aí vai e suspende, e desconta do dia, às vezes já quase no finalzinho do expediente, faltando duas horas, três horas! Espera o cara trabalhar seis horas, porque não bota logo no começo?! (Homem, 27 anos)

Quando dá problema na balança, a gente às vezes pode passar peso a mais, aí a carga foi grande. Ele pegou e disse que não era pra trabalhar desse jeito. Eu disse: "Mas a culpa não foi minha, foi problema na balança!”, ele disse: "Eu não quero saber”. Pronto, me deu a suspensão de dois dias, aí eu perdi um dia de trabalho e o outro, só porque eu passei uma carga grande. (Homem, 27 anos)

A suspensão tem um significado objetivo para o operário diretamente envolvido. Ele perde um dia de trabalho, além de ser visto como alguém que não produz. A suspensão, em última instância, tem um significado simbólico para o restante dos trabalhadores da fábrica, que é a questão do castigo (ir para a salinha), da punição para quem não cumpre as metas, sinalizando também uma potencial demissão. Nesse sentido, Barreto (2003, p. 152) afirma:

As ordens devem ser recebidas passivamente como sinal de integração e adequação à política da empresa. Deve-se trabalhar em silêncio e quase invisível, fazer horas extras ou produzir o determinado, sem se lastimar. Negar ou contestar as ordens é desobediência que deve ser punida, servindo de exemplo para que os outros companheiros que devem continuar produzindo. 
Como se trata de ocupações que não requerem capacitação formal, escolar ou universitária, e o contingente de desempregados é grande, os trabalhadores ficam em uma situação de fragilidade diante de tamanha pressão e humilhação, uma vez que, embora não existam, na região, estudos que mostrem os índices de rotatividade, há um grande número de saídas de trabalhadores e igual entrada de outros, por designação da empresa ou porque muitos não suportam mais continuar na produção diante de tanto sofrimento. Assim, o medo e a humilhação são colocados como instrumentos de gestão. Essas pressões se agravam ainda mais devido à fragilidade dos vínculos coletivos ali presentes, pois a rotatividade e o medo atrapalham a criação de vínculos que poderiam permitir reivindicações de mudança. Dessa maneira, não há a estruturação do "viver-junto" (DEJOURS; BÈGUE, 2010, p. 34), de modo que nem mesmo estratégias coletivas de defesa conseguem se erigir contra o sofrimento e cada trabalhador fica só diante da enorme pressão.

Configuram-se, então, formas de pressão para que as metas estabelecidas sejam atingidas, amparadas pela coação, pela humilhação e pelos constrangimentos dos trabalhadores: é o assédio organizacional mostrando sua face. Dessa maneira, os objetivos da produção colocam-se como justificativa para maltratar e humilhar os trabalhadores, ou seja, "[...] é sempre em nome de um trabalho que se legitima o 'dever de violência' por parte dos líderes” (DEJOURS, 2007, p. 132). Trata-se de uma forma de gestão que humilha, constrange e desconsidera totalmente o trabalho, o que leva a uma degradação do tecido social dentro e fora do meio de trabalho (DEJOURS; BÈGUE, 2010), visto que os trabalhadores levam as consequências do que ali vivenciam para suas vidas fora do trabalho. Tal quadro se agrava quando exercido sobre pessoas que estão com agravos ou portando doenças relacionadas ao trabalho ainda não diagnosticadas, mas com sintomas e dores presentes. Nesse momento, o assédio passa a ser especialmente dirigido para os adoecidos: o assédio moral organizacional transmuta-se em assédio moral interpessoal.

\section{Agravos e sintomas: motivos de humilhações e cons- trangimentos}

$\mathrm{Na}$ indústria onde trabalhavam os portadores de LER/DORT participantes da pesquisa que gerou esse artigo, o assédio moral foi confirmado em várias situações de trabalho. Entretanto, é a partir do adoecimento, juntamente com a baixa de produtividade, que as situações de degradação da integridade, da moral e da ética são inegavelmente claras. Em todos os relatos analisados, há rastros de humilhação, medo, vergonha e culpa, direta ou indiretamente, sob forma de coação, chantagem e pressão. As situações vivenciadas denunciam que o assediado é subvertido em sua relação com a própria saúde antes mesmo de se "descobrirem" doentes.

Imaginar que a dor que se apresenta agora é fruto de mero cansaço e não terá resultados indesejáveis em longo prazo faz parte da negação, que é o mecanismo de defesa psíquico mais comumente utilizado:
Primeiro eu comecei a sentir uma dorzinha de cabeça e aqui na nuca, aí eu falei com um funcionário lá, ele já tem 10 anos que trabalha lá. Eu perguntei pra ele: "Você sente alguma coisa?”, ele disse: "Sinto, mas é normal!". "Você já se afastou?" e ele disse: "Não eu faço fisioterapia, mas nunca me afastei não!" (Mulher, 30 anos)

Eu pensei que era normal, achei que era do trabalho, que ia passar, mas só fazia piorar! (Homem, 20 anos)

Quando o trabalhador percebe que não tem mais condições de atingir a meta de produção, inicia-se uma trajetória de busca de resolução de seu problema de saúde, que é vivido de forma solitária, uma vez que não conta com o coletivo para amparar-se. O medo gerado pela potencial perda de emprego ao adoecerem gera um sofrimento que não é compartilhado com os colegas de trabalho e, em alguns casos, sequer com os familiares.

Os trabalhadores relatam vivências de medo e isolamento com a situação de doença. Não contam aos colegas os problemas por que estão passando e omitem as dores:

Eu não contei pra ninguém, porque lá não pode tá falando demais, qualquer coisa eles colocam pra fora. (Homem, 24 anos, portador de tendinite no punho)

Segundo Barreto (2003, p. 36), a "omissão dos sintomas é uma prática comum entre os trabalhadores”, o que reflete simultaneamente um misto de esperança de uma reabilitação espontânea, ou seja, esperam ficar bons sem ter que sofrer o preconceito de estarem doentes, e do medo de perder o emprego. Suportam as dores até quando é possível, em termos físicos e psíquicos:

A doença só se manifesta na fábrica quando a dor é insuportável, rompendo o silêncio dos órgãos do corpo submetido, que já não consegue cumprir as metas preestabelecidas. A esperança estrangulada dá visibilidade à enfermidade, que por certo tempo manteve-se oculta na fronteira da dor e dos múltiplos medos. (BARRETO, 2003, p. 36)

\section{(Des)cuidados médicos}

Quando a esperança de melhorar se acaba com a transformação dos sinais e os sintomas da doença, o trabalhador não tem outra saída senão consultar um médico. Esse é um momento recheado de ansiedade, angústia e humilhações. As humilhações sofridas, em alguns casos, geram sérios transtornos emocionais, como vergonha e sentimento de culpa. Misturados ao medo, são coagidos por um sentimento de resignação, razão por que relutam em procurar ajuda médica.

Evitam ao máximo ajuda para não consolidar o medo de todas as injúrias ouvidas de que são manhosos e que estão reclamando por uma dor insignificante e para manter a crença de que não estão ficando doentes. A partir do que dizem os entrevistados, esse fato é intensificado na própria empresa, na enfermaria. Ocorre uma banalização dos problemas apresentados pelos operários. Os profissionais de saúde parecem 
desenvolver a síndrome da desafetação (SELIGMANN-SILVA, 1995), perdem o afeto, o sentimento em relação às questões colocadas pelos doentes:

Quando eu sofri o acidente, que caiu várias mantas no meu punho, eu senti o estralo, corri pra enfermaria [...], passaram gelo, quando eu voltei o supervisor disse que eu tava era com manha! Aí baixei a minha cabeça, voltei pra minha máquina e fui trabalhar! (Homem, 21 anos)

Eles lá não querem saber se você ta sentindo dor não, ia lá pra enfermaria só tomava um remédio e já voltava pro trabalho, não tinha nem descanso nem nada, nem eles mudam você de função lá dentro. (Homem, 20 anos)

A própria ida à enfermaria, acompanhada de um imediato retorno ao posto de trabalho, determina que sentir dor não é justificativa suficiente para atrapalhar o processo de produção. Vemos, então, que alguns são coagidos, subvertidos diretamente, em detrimento da própria saúde e ficam amedrontados, o que os desencoraja a procurar ajuda médica. Vemos que o presenteísmo é vivenciado também pela coação que se exerce contra aqueles que apresentam algum problema de saúde.

Quando decidem ir ao médico, outro problema sério e grave instaura-se, visto que isso envolve nuances jamais imagináveis. Os trabalhadores são impelidos a procurar apenas o médico e os serviços fisioterápicos fornecidos ou indicados pela própria empresa:

O médico não deu atestado, atestado só de um dia, eu até estranhei, a pessoa dizer que ta com dor e o médico não passar exame, tomografia ou ultrassom, aí eu desisti, deixei pra lá, a pessoa não pode ta mexendo com gente grande! (Homem, 27 anos)

Os operários não confiam mais nos serviços médicos oferecidos pela empresa ou encaminhados por ela, pois percebem que não há uma imparcialidade no tocante à relação médico-empresa. Preferem procurar outros profissionais indicados pelos próprios colegas de trabalho:

Ah, o outro médico me tratou super bem, me deu o que eu precisava, me deu autorização pra fazer ultrassom e tomografia da coluna. (Homem, 27 anos)

Eu fiz os exames tudinho, aí o médico fez e não acusou nada, aí passou ultra-som e acusou o problema no ombro, só que eu continuei com a dor, deu tendinite, [...] continuei com a dor nas costas, no pescoço, aí eu voltei pro médico, ele passou outros exames, passou uma ultrassonografia, aí acusou. (Mulher, 30 anos)

Vemos aqui dois dos muitos discursos proferidos sobre esse tipo de atuação médica. Até o atendimento pelo médico da empresa reveste-se, de maneira um pouco mais sutil que no chão de fábrica, do assédio moral dirigido a essas pessoas. Alguns operários, ao passarem pelo primeiro médico, voltavam ao trabalho mesmo sentindo dor, acreditavam no diagnóstico médico. Achavam estranha a ausência de exames complementares para se estabelecer um diagnóstico mais preciso e o fato de os remédios não serem suficientes para aliviar a dor. Nesse caso, coloca-se o problema da ausência de um diagnóstico corroborado por exames complementares em fases iniciais e interme- diárias do processo de adoecimento, justificando, muitas vezes, o que alguns médicos reputam, desde a origem da discussão sobre as doenças ocupacionais, a uma invenção do quadro por parte dos trabalhadores, como encontrado também por Verthein e Gomez (2001).

Somente quando já se encontravam impossibilitados de trabalhar é que recorriam a outros profissionais, quando os problemas de saúde já estavam mais graves. Nesse sentido, o sofrimento permanece silenciado na fábrica e só aparece na forma de doença, que pode levar ao afastamento definitivo do trabalho.

Ainda assim, relatam que, quando procuravam ajuda de outros profissionais que não os da empresa ou indicados por ela, preferiam fazê-lo escondidos e em dias em que não trabalham para evitar que fossem advertidos pelos supervisores. Uma ida ao médico já é um motivo para entrar no rol dos discriminados. Os operários descrevem que, para não entrar em desavença com a indicação feita pela empresa, acabam indo aos médicos sugeridos, contudo percebem que o atendimento sempre fica aquém dos cuidados necessários aos problemas que apresentam:

Lá só tem babão, também não acreditam que a pessoa esteja doente, eles dizem que o cara não tá doente, que nem o médico que eu fui. Disse que eu tava bonzinho, podia voltar a trabalhar. Não fez exame, não fez nada! Foi indicado pela firma. Na enfermaria, eu cheguei lá com dor e pedi uma ordem pra ir pro ortopedista, ela foi botou lá e indicou, aí eu fui, mas quando eu cheguei lá ele disse isso, eu peguei e resolvi ir pra outro médico. (Homem, 20 anos)

Mandaram eu procurar um médico lá[...], o médico pegou e não faz nada, eles mandam pro médico daqui, eles não passam nada, só fisioterapia e pronto, a fisioterapia é lá na clínica dele [...] Aí eu fui lá, não sabia de nada. Ele perguntou o que eu tinha, eu disse: "Dor na coluna!", ele disse: "Dor na coluna, tá certo! Você aguenta trabalhar?”, eu disse que não aguentava não... Ele disse: "Mas rapaz, você com um físico desse?!" Mandou eu tirar a camisa: "Você com um físico desse sentindo dor?". "Mas doutor! Isso aqui é por fora, eu to forte por fora, mas por dentro eu sinto dor!”. Ele ficou só rindo! (Homem, 27 anos)

Um ponto muito reiterado em Oliveira e Silva (2006) remonta à "via crucis do trabalhador", que tem que provar a própria doença quando da descrença dos médicos. No desejo de provar o nexo da doença com o trabalho, o trabalhador se submete à repetição de exames e à procura de médicos indicados pela própria empresa. A situação de humilhação chega a tal nível que alguns operários têm que se deslocar para a capital, João Pessoa, para fazerem novamente os exames já realizados em Campina Grande, em laboratórios e clínicas indicados pela empresa. Um operário comentou que fez exames em uma clínica e, quando foi buscá-los, alguém da empresa já os havia retirado, ultrajando o direito do cidadão, tomando-lhe o direito de pegar e ver em primeira mão o próprio exame. Isso confirma o pensamento de Barreto (2003, p. 37), ao afirmar que "a perda da saúde é acompanhada pela perda da dignidade". Ainda é muito comum o entendimento de que o trabalhador doente, para não trabalhar, inventa a própria doença, é preguiçoso, mentiroso. Se- 
gundo a citada autora, "essas afirmações decompõem o modo de ser dos trabalhadores".

Ainda mais grave que isso é a falta de ética dos profissionais de saúde da empresa, quando omitem os agravos decorrentes do trabalho nos casos em que o trabalhador continua na sua atividade, trabalhando:

Os médicos que os atendem em ambulatórios das empresas incorrem frequentemente em problemas éticos: omitem os riscos existentes à saúde; não fornecem os resultados dos exames realizados ou cópia de prontuário quando solicitados; não notificam as doenças e os acidentes de trabalho; ignoram e ridicularizam os atestados dos colegas, responsabilizando-os pelo fato de adoecerem ou se acidentarem. (BARRETO, 2003, p. 37)

Um dos operários entrevistados na primeira etapa da pesquisa nos mostrou uma cópia do encaminhamento da médica da empresa ao setor onde ele trabalhava, indicando algumas limitações para que o trabalhador conseguisse executar sua atividade. Em seu encaminhamento, a médica atesta o agravo que acomete o operário, porém não o afasta da função. Ao contrário, manda-o de volta ao setor com um laudo descrevendo que ele tem condições de continuar o trabalho, porém com restrições da atividade, restrições estas que impedem que a atividade seja realizada naquele cargo. Publicamos abaixo, com autorização do trabalhador, o teor do encaminhamento dado pela médica da empresa:

O colaborador [fulano] encontra-se com o diagnóstico de Osteoartrose [...] com estado clínico presente, o mesmo poderá exercer sua atividade laboral com alternância de postura (em pé e sentado), sendo contra indicado o deslocamento e pegar peso e o agachamento.

Esse encaminhamento foi escrito em maio de 2004 - o operário estava afastado até a data do término da pesquisa (julho de 2007). Submeteu-se a uma cirurgia para colocar uma prótese, mas não foi bem-sucedida. O operário foi encaminhado pela Previdência Social para aposentadoria por invalidez. Ele exercia suas atividades carregando caixas para abastecer as carretas. É, no mínimo, um contrassenso dizer que não é indicado que um trabalhador pegue peso quando sua função é pegar peso. Segue abaixo o seu relato, em que ele fala com indignação da posição médica. Sua expressão facial, ao relatar tal situação, sugere incredulidade. Parecia não acreditar que fosse possível ouvir tal absurdo:

Não, logo no começo quando eles viram que eu num tava aguentando mesmo, queria botar eu numa cadeira de rodas... pra trabalhar. Numa cadeira hidráulica. Pra ir trabalhar... numa cadeira de rodas!! (Homem, 35 anos)

Só depois de passar por todo esse desrespeito, o trabalhador decidiu procurar outro profissional fora da empresa:
A médica de lá. Aí ela disse lá "é o jeito falar com [empresa] aí pra comprar uma cadeira de hidráulica”! aí foi quando eu vi, disse por lá. Aí procurei um médico. Quem é o gerente lá que ia me aceitar trabalhar com cadeira de rodas... doente? (Homem, 35 anos)

O operário percebeu que estava sendo induzido a pedir demissão:

Cadeira de roda??? Oxe, eu... Eles tava me pressionando pra eu pedir as conta, né?! Não tinha condição! (...) É pra vê a pressão, pra vê, né? (...) Eu acho que foi na pressão que ela pensou, né? Mas eu não tinha mesmo condição. Ela não chegou pra dizer assim... que... eu não tinha mais condição. (Homem, 35 anos)

O que torna ainda mais antiética a postura desses médicos é o fato de que são justamente eles que deveriam "dar a conhecer as formas de organização do trabalho geradoras de isolamento e diagnosticar à montante os sintomas de alerta” (PEZÉ, 2008, p. 42).

Outro operário relatou que sofreu um acidente de trabalho e a empresa não quis emitir a Comunicação de Acidente de Trabalho (CAT), alegando doença comum. Essa omissão levou a um agravamento sério do problema apresentado. Os trabalhadores coagidos acabam não procurando ajuda, pois muitos se sentem envergonhados, mantêm-se defensivamente em silêncio (DEJOURS, 1992) e, para provar que não são "maricas e moles”, suportam calados as dores.

Segundo o relato desse trabalhador, o problema se agravou e ele teve que se submeter a uma cirurgia no punho. A emissão da CAT só foi possível posteriormente porque ele passou a ser portador de LER/DORT, com tendinite no punho e bursite nos dois ombros:

Depois de quase três meses é que, no caso, eu consegui emitir a CAT, aí o médico pegou, assinou e eu levei pra lá. No caso eles colocaram como auxílio doença ${ }^{5}$, em vez de acidente de trabalho (...) A própria Doutora (...) me disse que eu estava apto pra trabalhar, e que eu já havia entrado com essa doença lá dentro! E eu disse: "quer dizer Doutora que vocês estão contratando qualquer um doente é?” (Homem, 21 anos)

\section{Atestado médico: uma fonte de pressão psicológica no trabalho}

Os trabalhadores sofrem os mais variados tipos de pressão para dar conta da produtividade. Esse fato é claramente agravado quando adoecem. Uma forma de pressão psicológica exercida na empresa estudada e referenciada pelos trabalhadores é a questão de não apresentar atestado médico. Um funcionário é sempre bem visto quando nunca adoece e sempre mal visto se já tiver apresentado algum atestado durante o período em que trabalhou.

\footnotetext{
${ }^{5} \mathrm{O}$ auxílio doença acidentário só é concedido pelo INSS quando a CAT é emitida pelo médico da empresa ou pelo médico particular (dificilmente um desses dois profissionais emite a CAT). As CATs são emitidas pelo Cerest ou por outras entidades capacitadas para tal. Contudo, o INSS só concede o auxílio doença previdenciário. A diferença entre ambos é que o auxílio doença acidentário, além de outras coisas, permite ao trabalhador a estabilidade no emprego por um dado período de tempo após o afastamento. As empresas, por sua vez, não emitem a CAT, porque, assim, terão um funcionário incapacitado com estabilidade empregatícia, o que não é interessante.
} 
Durante todo o percurso de coleta de dados, o que foi mais reiterado, reafirmado, compartilhado entre os operários gira em torno dos atestados médicos. O que importa, para os gestores, "não é a saúde do trabalhador, mas a saúde necessária à produção" (RIBEIRO, 1999, p. 203). Por força dessa pressão psicológica, os trabalhadores fazem de tudo o que as suas forças físicas e psíquicas suportam para continuar trabalhando. Em nome do emprego, negam sua doença, mesmo podendo ser atestada por um médico:

A primeira vez eu pedi pro médico pra não botar atestado. Não coloquei o atestado, porque assim, você trabalha até o seu limite, muitas vezes você acha que dá pra trabalhar, eu já trazia analgésico de casa, ou em casa tomava dorflex ou até injeção, trabalhava com dor, mas teve uma hora que eu comecei a ir direto pra enfermaria. (Homem, 26 anos)

Uma vez o supervisor mesmo me disse: "É, fulano, você tem muito atestado, sabe que não pode botar esses atestados todos!" [...] "Você sabe que não pode ficar com esse monte de atestado aqui, que você se complica e não vão mais confiar em você!". (Homem, 49 anos)

Sim... A gente passa por constrangimento, dizem que a pessoa tá com manha, diz que tá fazendo corpo mole, que a pessoa tá querendo se afastar, se encostar. (Homem, 27 anos, portador de hérnia de disco e tendinite no punho e ombros)

Nessa linha, Schatzmam et al. (2009, p. 21) afirmam:

Uma postura discriminatória pode, muitas vezes, conduzir à pratica do assédio moral. Por exemplo, há relatos de pessoas que passaram a sofrer processos de assédio moral no trabalho a partir do momento em que é revelada sua orientação homossexual, ou uma doença crônico-degenerativa de que é portador (como a AIDS, o câncer, ou a LER/DORT), ou de uma vinculação política ou sindical, etc.

Segundo Barreto (2003, p. 129), os adoecidos, em particular, sabem que o caminho para o desemprego fica aberto após algum evento, principalmente com a apresentação de um atestado de afastamento do trabalho por um período maior. Mais grave ainda, o indivíduo trabalha doente pelo medo de ser demitido, principalmente porque, doente, não encontrará novo emprego. Ainda segundo a autora, "o medo de perder o emprego aumenta a dependência em relação à empresa, o trabalhador entrega-se à produção e silencia a dor”.

\section{Outras situações de assédio moral}

\section{Os que mudam de função}

Outro foco dos assédios são os trabalhadores que precisam mudar de função devido à sua doença. Essa situação os coloca em uma posição desconfortável. Ficam nas mãos dos superiores que definem onde os colocar. Nesse processo, acontece intensamente o assédio moral. O trabalhador é pressionado, coagido e constrangido e são estabelecidas atividades incompatíveis com sua capacidade física:
Tem agora rodízio, mas eu não tô conseguindo montar, porque tem que fazer mais esforço, tem que ser muito rápido a produção e eles exigem muito, eu não estava conseguindo e pedi pra mudar de função, mas eu tive que comprovar, eu não podia chegar e dizer “não estou podendo!”. Lá não tem isso não, você tem que comprovar: Eu provei que estava com um problema no ombro, não estava nem no pescoço ainda. (Mulher, 30 anos)

Essas exigências buscam fazer com que o trabalhador peça demissão. Na mudança de função, os operários são submetidos à realização de tarefas para as quais não foram contratados, sendo encaminhados para executar tarefas que eles mesmo consideram inferiores, sentindo-se, portanto, inferiores, humilhados:

Me senti envergonhado já, de varrer o chão, coisa que não tem nada a ver, de lavar o piso me botaram também, coisa que não tem nada a ver com minha função, nada! (Homem, 20 anos)

\section{Assédio misto}

O assédio moral misto se efetiva na conjunção do assédio moral vertical descendente (praticado pela hierarquia) e o horizontal (que vem dos colegas de trabalho). Hirigoyen (2006, p. 114) refere que:

quando uma pessoa se acha em posição de bode expiatório, por causa de um superior hierárquico ou de colegas, a designação se estende rapidamente a todo o grupo de trabalho. A pessoa passa a ser considerada responsável por tudo que dê errado. Bem depressa ninguém mais a suporta e, mesmo que alguns não sigam a opinião do grupo, não ousam anunciar. (2006, p. 114)

O modo como o trabalho nos grupos e nas células está organizado, bem como os incentivos - premiações prometidas para quem cumpre a produção e se destaca - criam um clima de competição entre os trabalhadores. Embora pareça um trabalho em equipe, o que se constitui entre eles é um trabalho coletivo precário e temporário (GONDIM, 2007). Cada um tem que dar o máximo de si para conseguir a produção, caso contrário, será repreendido individualmente e coletivamente, porque a vigilância é individual e grupal. A produção total é a soma das partes da atividade de cada posto. Nesse contexto, o assédio moral se apresenta também na sua forma horizontal. Alguns operários se sentem humilhados pelos próprios colegas de trabalho:

\footnotetext{
O setor que eu trabalho reclamam as meninas, justamente assim, elas se sentiam muito agredidas, não pelo supervisor, mas por gente que trabalha lá dentro, porque elas ficam humilhando... "Canto de doente era no INSS! Se não tem condições de trabalhar peça pra pedir as contas e vá pra casa!”. Elas reclamam, solta piadinha, porque justamente isso, até comigo mesmo. (Mulher, 40 anos)
}

Por fim, os que retornam ao trabalho, depois de afastados, muitas vezes, não suportam a "rejeição" sentida e sofrida pelos colegas e superiores e pedem demissão ou fazem acordos com a empresa. Ao invés de os trabalhadores se ampararem uns aos outros, é a competição 
que se torna regra, gerando consequências desastrosas para quem vive aquele meio de trabalho (DEJOURS; BÈGUE, 2010). O pedido de demissão é o destino dos que não suportam as pressões e as dificuldades encontradas tanto na empresa, quanto nos consultórios médicos. Outro aspecto que provoca o pedido de demissão é quando o INSS faz a reabilitação do funcionário e estabelece o retorno daquele segurado à empresa, mas quando ele retorna, ainda se sente incapacitado para trabalhar, pois ainda sente muitas dores:

Pra não ficar mais doente ainda, e também porque eu já ia pedir as contas, ia pedir pra sair, pra não ficar mais doente, também porque é muita pressão lá. Eu não aguento não... Cobrança demais, produção, os caras babão lá, querendo ser mais que a pessoa, aí deu vontade de sair já. (Homem, 20 anos)

Em pesquisa realizada no Québec, Genest, Leclerc e Maranda (2005) falam de uma recusa, de uma fuga, uma esquiva dos que sofrem o assédio moral (humilhações, depreciações e vergonha). Para os autores:

a retirada [retrait] pode levar a um mecanismo de auto-proteção das pessoas que são alvo ou que podem ser. Em outras situações, ele pode designar uma cegueira voluntária de parte das pessoas que deveriam normalmente intervir. Globalmente, ele se relaciona a um recuo ou a uma falta de ação a um comportamento julgado inaceitável. ${ }^{6}$ (p. 1)

Os autores entendem que os operários se valem de atestados de saúde, férias prolongadas, afastamentos temporários, troca de cargos.

Podemos levantar algumas linhas de análise para o assédio moral vivido pelos operários entrevistados, dizendo que três mecanismos de tentativa de retirar-se parcialmente daquele meio de trabalho são utilizados para que continuem trabalhando:

1. Atestado médico: de fato, percebemos que há uma fuga, um alívio da tensão vivida por eles enquanto estão afastados do trabalho. Quando perguntados como está o período de afastamento, percebemos um alívio, um desabafo. Aliado a isso, paradoxalmente, a "falta" que a ausência do trabalho impõe: diminuição da libido, papel social, papel na família e, enfim, a saúde. Estar afastado do trabalho por problemas de saúde os coloca em uma posição de desequilíbrio emocional. De um lado, o alívio da dor e da pressão; de outro, o sentimento de inutilidade e incapacidade.

2. Férias: alguns esperam o momento das férias para cuidar da saúde, porquanto acreditam que podem aguardar esse momento e, ainda, que esse período seja suficiente para voltar curado. Todavia, muitas vezes, isso não funciona. Muitos relatam que é justamente nas férias que os agravos pioram. Às vezes, não estão sentindo muita dor e estranham, pois, com o advento das férias, as dores surgem. É nas férias que surge uma maior aten- ção com o corpo e a mente volta-se mais para ele. O que antes era coberto pelo uso "necessário e quase obrigatório" de estratégias defensivas para continuar dando conta do trabalho, retorna como necessidade orgânica de cuidados. Um corpo que não estava bem, mas que se mostrava "escondido", agora "aparece" como um corpo que precisa ser cuidado. É por isso que dizemos que o sujeito levou uma "rasteira" do inconsciente.

3. Isolamento: o isolamento não só inerente ao tipo organização do trabalho adotada (como vimos durante toda a explanação dos resultados), mas é intensificado pelo medo, isolamento imposto pela pressão, pela coação e pela humilhação de superiores e colegas de trabalho.

Em face das estratégias de defesa apontadas serem prioritariamente individuais, os trabalhadores, na maioria das vezes, só expressam seus sentimentos aos médicos: "é a individualização máxima do sofrimento e sinal de que as defesas coletivas não são mais eficazes” (DEJOURS; ABDOUCHELI; JAYET, 1994, p. 90).

Outra atitude defensiva consiste em evitar todas as ocasiões de discussão. Os trabalhadores ouvem calados e continuam no seu processo de trabalho. Quando são cobrados, ocorre o presenteísmo, ou seja, fazem de tudo para permanecer trabalhando, mesmo que à custa de grande sofrimento. Voltam-se mais para seu trabalho, esforçam-se ao máximo, pois, dessa forma, evitam o contato direto com colegas de trabalho e superiores, pois estão comprometidos com sua máxima produção. Acelerar o trabalho tem um preço alto - é a transposição do sofrimento psíquico para o corpo.

\section{Considerações finais}

Neste artigo se apresentou a ocorrência de assédio moral interpessoal e assédio moral organizacional. $\mathrm{O}$ assédio moral organizacional mostrado neste artigo é um produto das práticas de gestão ocorridas em uma determinada empresa, calcadas em metas sempre crescentes, cobranças e vigilância constante nos locais de trabalho. A gestão adota a presença de líderes e supervisores para acompanhar o desempenho dos trabalhadores, que são avaliados minuto a minuto, hora por hora, e cobrados quando não estão no ritmo da meta a ser atingida ao final da jornada de trabalho. Este modo de gestão é coletivo, na medida em que submete todos ao mesmo processo, mas a avaliação do desempenho é exercida de modo individual visando fazer com que cada um sinta a necessidade de dar o máximo de si. Isto deixa os bem-sucedidos em uma situação de menor insegurança e os outros em uma situação de grande fragilidade, naquilo que Castel (2001) chamou de individualismo negativo, só tendo suas próprias forças para contar e sem poder se valer delas no caso de adoecimento. Apesar desse quadro ter sido descrito a partir da experiência de trabalhadores em

${ }^{6}$ Tradução livre. 
uma empresa, defendemos que ele se encontra disseminado no cenário empresarial, corroborando o que apresentam diversos autores como Dejours (2007), Dejours e Bègue (2010), Gaulejac (2007) dentre outros.

Através dos depoimentos pudemos perceber a ocorrência do presenteísmo em face das cobranças e das vigilâncias constantes. São trabalhadores que mesmo com dores, alguns deles já tendo sido afastado do trabalho e voltado depois, continuam exercendo suas atividades, tendo seu quadro clínico agravado e o nível de sua produtividade comprometido, além de enormes prejuízos em sua vida pessoal. O tipo de organização do trabalho empregada desgasta a saúde física e mental das pessoas, de modo que não se trata aqui de idiossincrasias daqueles que trabalham, mas da organização do trabalho, ela mesma produtora de adoecimento.

Os resultados evidenciam um quadro de assédio moral interpessoal que está bem configurado nas atitudes de humilhação e coação dos trabalhadores que não conseguem mais acompanhar o ritmo exigido. Identificamos como os trabalhadores são coagidos a não procurar ajuda médica. Procurar o médico, para os trabalhadores, pode significar a perda da capacidade e da vitalidade, que são atributos valorizados na empresa. Mais do que isto, pode levar ao desemprego. O assédio moral interpessoal gera a dúvida de procurar ou não o médico em virtude de todos os aspectos de humilhação, exclusão e pressão que recebem no ambiente de trabalho. Evidenciamos que os gestores pressionam os trabalhadores fazendo alusão ao desemprego que existe na região. O trabalhador, em geral com baixo nível de escolaridade e de formação profissional, sabe que existe uma lista de espera para ingressar na empresa e isso é utilizado contra eles.

O assédio moral interpessoal foi verificado tanto na sua forma vertical, como horizontal, mostrando a difusão de uma lógica de diminuir a outra pessoa, ficando não apenas restrita à chefia, mas distribuída entre os trabalhadores, diminuindo a possibilidade de formação de coletivos que possam lutar pela modificação de tal quadro. O assédio torna-se evidente no caso dos trabalhadores que retornam ao trabalho depois de uma licença médica para tratamento de saúde. Nesses casos, os supervisores cobram intensamente o alcançar das metas, dizendo que aqueles trabalhadores não tinham mais condições de acompanhar o ritmo. Diante disso, ao invés dos colegas de trabalho apoiarem os adoecidos, acabavam por rejeitá-los por não conseguirem fazer a tarefa conforme as exigências da empresa.

Esta ocorrência de assédio moral interpessoal e organizacional é mais grave ainda já que é praticada contra trabalhadores com doenças relacionadas ao trabalho. Fragilizados pela doença que se instala dia a dia e lutando para continuar em atividade, os trabalhadores são vítimas de violência cotidiana configuradas nas atitudes de humilhação, exclusão, pressão etc. As consequências atingem a saúde física e mental dos trabalhadores e sua família. Na maioria dos casos analisados, os trabalhadores ou pediram demissão por não aguentarem a pressão, ou estavam em benefício previdenciário, com casos de mais de um ano de afastamento do trabalho.

A falta de uma organização coletiva de classe torna nulo o movimento de reivindicação e denúncia contra as situações de violência de que são vítimas. Os trabalhadores desconhecem o trabalho do sindicato, muitas vezes desconhecem até a existência deste. Esses trabalhadores vivem sozinhos, mesmo havendo vários deles na mesma situação, de forma que não conseguem se organizar para reivindicar mudanças. Não compartilham seus direitos e deveres, não se solidarizam um com a causa do outro. A lógica da organização do trabalho gera o silêncio entre os trabalhadores e constrói barreiras enormes para a construção de uma luta coletiva. O quadro é sombrio e por hora não parece haver perspectivas de transformação.

\section{Contribuições de autoria}

Silva, E. F.: coordenou e orientou a pesquisa, participou da discussão, da análise e da interpretação dos dados, além da elaboração e da revisão do manuscrito e da aprovação final da versão publicada. Oliveira, K. K. M.: participou do projeto, da coleta de dados, da discussão, da análise e da interpretação dos dados, além da elaboração e revisão do artigo. Zambroni-de-Souza, P. C.: contribuiu na análise dos dados, na elaboração e na revisão do manuscrito e na aprovação final da versão publicada.

\section{Referências}

ANTUNES, R.; ALVES, G. As mutações no mundo do trabalho na era da mundialização do capital. Educação e Sociedade, Campinas, v. 25, n. 87, p. 335-351, maio/ ago. 2004.

BARRETO, M. M. S. Violência, saúde e trabalho: uma jornada de humilhações. São Paulo: Educ, 2003.
BRASIL. Ministério do Trabalho e Emprego. Empregos formais (CAGED) no Nordeste. 2010. Disponível em: <http://estatistica.caged.gov.br/ cons...10\&anoCPT $=2010>$. Acesso em: 18 out. 2010,

CASTEL, R. A metamorfose da questão social: uma crônica do salário. Petrópolis: Vozes, 2001. 
COUTO, H. A.; MORAES, L. F. R. Novas perspectivas na prevenção dos distúrbios dolorosos dos membros superiores: o entendimento dos fatores de organização do trabalho e psicossociais envolvidos em sua origem. Revista Brasileira de Medicina do Trabalho, Belo Horizonte, v. 1, n. 1, p. 43-58, jul./set. 2003.

DEJOURS, C. A loucura do trabalho: estudo de psicopatologia do trabalho. São Paulo: Cortez: Oboré, 1992. Le Travail entre banalisation du mal et émancipation. Oct. 2001. Disponível em: <http:// perso.wanadoo.fr/christian.crouzet/smpmp/imagesSMT/DEJOURS\%20oct\%202001.pdf>. Acesso em: 25 Abr. 2006.

. A banalizalização da injustiça social. Rio de Janeiro: FGV, 2007.

. A avaliação do trabalho submetida à

prova do real. São Paulo: Blücher, 2008.

DEJOURS, C.; ABDOUCHELI, E.; JAYET, C.

Psicodinâmica do Trabalho: contribuições da Escola Dejouriana à análise da relação prazer, sofrimento e trabalho. São Paulo: Atlas, 1994.

DEJOURS, C. BÈGUE, F. Suicídio e trabalho: o que fazer? Brasília: Paralelo 15, 2010.

EBERLE, A. D.; SOBOLL, L. A. P.; CREMASCO, M. V. F. Compreensões sobre o assédio moral a partir da Psicodinâmica do Trabalho. In: SOBOLL, L. A. P.; GOSDAL, T. C. Assédio moral, interpessoal e organizacional: um enfoque multidisciplinar. São Paulo: LTr, 2009. p. 105-138.

FEDERAÇÃO DAS INDÚSTRIAS DO ESTADO DO PARANÁ. Principais empresas exportadoras: base 2008. Disponível em: <http:/fiepb.com. br/fluxodecomercio/arquivos/comercioexterior/ informacoes_setor/Principais_Empresas_Exportadores R3.pdf>. Acesso: em 20 set. 2010.

FREITAS, M. E.; HELOANI, J. R.; BARRETO, M. Assédio moral no trabalho. São Paulo: Cengage Learning, 2009.

FREITAS, L. G.; LIMA, S. C. C.; ANTONIO, A. C. Análise psicodinâmica do atendimento de vítimas de assédio moral no trabalho. In: MENDES, A. M. (Org.). Violência no trabalho: perspectivas da psicodinâmica, da ergonomia e da sociologia clínica. São Paulo: Universidade Presbiteriana Mackenzie, 2010. p. 123-137.

GAULEJAC, V. de. Gestão como doença social: ideologia, poder gerencialista e fragmentação social. Aparecida: Idéias \& Letras, 2007.

GENEST, C.; LECLERC, C.; MARANDA, M-F. Lês conduites de retrait comme stratégies défensives facu au harcèlement psychologique au travail. Pistes, v. 7 n. 3, nov. 2005. Disponível em: <http://www.pistes. uqam.ca/v7n3/articles/v7n3a5.htm > . Acesso em: 30 mars. 2005.
GONDIM, V. T. F. Os desdobros do trabalho: há constituição do coletivo de trabalho em uma empresa calçadista de Campina Grande? 2007. 46 f. Monografia (Graduação)-Departamento de Psicologia, Universidade Estadual da Paraíba, Campina Grande, 2007.

GOSDAL, T. C. et al. Assédio moral organizacional: esclarecimentos conceituais e repercussões. In: SOBOLL, L. A.; GOSDAL T. C. Assédio moral, interpessoal e organizacional: um enfoque multidisciplinar. São Paulo: LTr, 2009. p. 33-41.

HIRIGOYEN, M. F. Assédio Moral: a violência perversa no cotidiano. 8 ed. Rio de Janeiro: Bertrand Brasil, 2000.

. Mal-estar no trabalho: redefinindo o assédio moral. São Paulo: Bertrand do Brasil, 2002.

. Mal-estar no trabalho: redefinindo o assédio moral. 3. ed. São Paulo: Bertrand do Brasil, 2006.

INSTITUTO BRASILEIRO DE GEOGRAFIA E ESTATÍSTICA. Indicadores IBGE: pesquisa mensal de emprego: dezembro 2010a. Diponível em: <http://www.ibge.gov.br/home/estatistica/ indicadores/trabalhoerendimento/pme_nova/ pme_201012pubCompleta.pdf $>$. Acesso em: $10 \mathrm{fev}$. 2011.

. Cidades: Campina Grande. 2010b. Disponível em: <http://www.ibge.gov.br/cidadesat/topwindow. htm?1>. Acesso em: 25 nov. 2010.

INSTITUTO NACIONAL DE SEGURO SOCIAL. Norma técnica sobre distúrbios osteomusculares relacionados ao trabalho - DORT. Instrução Normativa INSS/DC № 98 de 05 de dezembro de 2003. Diário Oficial [da] União, Brasília, DF, 10 dez. 2003. Disponível em: <http://www.81.dataprev.gov.br/sislex/paginas/38/inss. dc/2003/98.htm>. Acesso em: 15 jun. 2010.

. Instrução normativa INSS/PRES nº 16 de 27 de março de 2007. Diário Oficial [da] União, Brasília, DF, 30 mar. 2007. Disponível em: < http://www010. dataprev.gov.br/sislex/paginas/38/INSS-PRES/2007/16. htm >. Acesso em: 15 jun. 2010.

LEYMANN, H. Contenido y desarrollo del acoso grupal/moral ("Mobbing”) en el trabajo. European Journal of Work and Organizational Psychology, v. 5, n. 2, p.165-184, 1996.

MATIAS, M. D. Assédio moral: humilhação e covardia no mundo do trabalho. 2004. 34 f. Monografia (Graduação)-Centro de Ciências Biológicas e da Saúde, Universidade Estadual da Paraíba, Campina Grande, 2004.

OLIVEIRA, K. K. M.; SILVA, E. F. O sofrimento psíquico em portadores de lesões por esforços repetitivos relacionadas ao trabalho (LER/DORT) na indústria do calçado em Campina Grande-PB. Campina Grande: Universidade Estadual da Paraíba, 2006. 63p. Relatório de Pesquisa de Iniciação Científica (PIBIC).

ORGANIZACIÓN INTERNACIONAL DEL TRABAJO. Proyecto de repertorio de recomendaciones práticas 
sobre la violência y el estrés em el sector de los serviços: una amenaza para la productividad y el trabalho decente. Ginebra, 2003. Disponível em: <http://www.ilo.org./public/spanish/support/publ/ intro/index.htm>. Acesso em: 10 nov. 2010.

PELI, P.; TEIXEIRA, P. Assédio moral: uma responsabilidade corporativa. São Paulo: Ícone, 2006.

PEZÉ, M. La souffrance au travail: état des lieux. Revue de la Gendarmerie Nationale, n. 228, p. 3743, 2008. Disponível em: <http://www.defense.gouv. fr/gendarmerie/content/download/136161/1185903/ file/228p37-44.pdf>. Acesso em: 26 jun. 2010.

RIBEIRO, H. P. A violência oculta do trabalho: as lesões por esforços repetitivos. Rio de Janeiro: Fiocruz, 1999.

SCHATZMAN, M. et al. Aspectos definidores do assédio moral. In: GOSDAL, T. C.; SOBOLL, L. A. P. (Org.). Assédio moral, interpessoal e organizacional: um enfoque multidisciplinar. São Paulo: LTr, 2009. p. 17-32.

SELIGMANN-SILVA, E. Os riscos da insensibilidade. In: FURTADO, T. (Org.). Recursos Humanos: a falência psicológica nas organizações. Rio de Janeiro: Editoração Ltda, 1995. p. 63-87.

. Acidentes de trabalho e a dimensão psíquica. Disponível em: <http://www.moodle.fmb.unesp. br/file.php?file=/52/Encontros/2010/Producao social_dos_AT/Edith_-_ACIDENTES_TRABALHO_ PSIQUISMO.pdf>. Acesso em: 19 out. 2010.

SOBOLL, L. A. P. Assédio moral/organizacional: uma análise da organização do trabalho. São Paulo: Casa do Psicólogo, 2008.

VALLETE, J. C. Subjectivité et action collective. Travailler: Revue Internationale de Psychopothologie et Psychodynamique du Travail, France, v. 2, n. 8, p. 73-86, 2002.

VERTHEIN, M. A. R.; GOMEZ, C. M. As armadilhas: bases discursivas da neuropsiquiatrização das LER. Ciências e Saúde Coletiva, São Paulo, v. 6, n. 2, 2001. Disponível em: <http://www.scielo. br/scielo.php?script $=$ sci_arttext\&pid $=$ S141381232001000200015\&lng $=p t \& n r m=i s o>$. Acesso em: 19 dez. 2009. 